\title{
PERSONALITY AND COGNITIVE ABILITIES AS PREDICTORS OF UNIVERSITY STUDENTS' ACADEMIC ACHIEVEMENT
}

Helena SMRTNIK VITULIĆ, Simona PROSEN

Faculty of Education, Ljubliana

UDK: 159.928.22-057.875(497.5)

Izvorni znanstveni rad

Primljeno: 8. 7. 2011.

In the current study the students' big five personality traits and specific cognitive abilities were included in predicting their academic achievement: grade point average (GPA) and grades from specific subjects. Two generations of first-year faculty students participated in the research: 203 students of primary education and 80 students of social pedagogy. Using hierarchical multiple regression analyses, non-verbal cognitive abilities, included in the first step of analyses, accounted significantly for $4 \%$ of the variance in grade in "science and mathematics" for primary education students, whereas verbal cognitive abilities explained $7 \%$ of variance in the GPA of social pedagogy students. The big five personality traits, included in the second step of analyses, significantly improved the prediction of grade in "psychology and didactics", for primary education students and overall grades for social pedagogy students, relative to the predictions based only on the cognitive abilities tests. Among the big five personality traits, measured with BFQ (Caprara et al., 1997), conscientiousness was the only significant predictor of certain grades for both student groups.

Keywords: academic achievement, university students, cognitive ability, personality, big five

$\triangle \quad$ Helena Smrtnik Vitulić, Faculty of Education, University of Ljubljana, Kardeljeva ploščad 16, 1000 Ljubljana, Slovenia. E-mail: helena.smrtnik-vitulic@guest.arnes.si

\section{INTRODUCTION}

Success in school has a major impact on future opportunities for students (Laidra et al., 2007). Several factors have been identified in relation to academic achievement, cognitive abilities 
DRUŠ. ISTRAŽ. ZAGREB GOD. 21 (2012) BR. $3(117)$

STR. 715-732

SMRTNIK VITULIĆ, H., PROSEN, S.: PERSONALITY AND.. and personality being among the most important (e.g. Bratko et al., 2006; Chamorro-Premuzic and Furnham, 2008; Di Fabio and Palazzeschi, 2009; Laidra et al., 2007). Cognitive abilities reflect what an individual can do, personality traits may provide information on what an individual will do (Furnham and Chamorro-Premuzic, 2004). Known factors associated with academic achievement have important implications for educators in structuring educational processes, aimed at improving academic performance of students (Smrtnik Vitulić and Zupančič, 2010).

The concept of cognitive abilities is a complex one, since many different models of cognitive abilities have been proposed. These models may include the idea of a general cognitive ability and/or specific cognitive abilities (Sternberg, 1985). Among the specific cognitive abilities Horn and Cattell (1966) identified the fluid and crystallized cognitive abilities, included in our study. Horn and Cattell (1966) defined fluid cognitive abilities as an individual's ability to reason, form concepts, and solve problems using unfamiliar information or novel procedures, whereas crystallized cognitive abilities include an individual's acquired knowledge, the ability to communicate one's knowledge, and the ability to reason using previously learned experiences or procedures.

Correlation between cognitive abilities and academic achievement is usually explained in the following terms: pupils, who are quick and eager to learn most probably, effectively manage academic-related problems in school and consequently obtain higher grades than their peers with lower cognitive abilities (Furnham and Chamorro-Premuzic, 2004). Research has shown that correlation between general cognitive ability and academic achievement appears to decline with age, being the highest in primary school and decreasing in secondary school and at university (e.g. Leeson et al., 2008; O'Connor and Paunonen, 2007; Poropat, 2009). These results may be explained in terms of highly selective samples of university students with respect to their higher cognitive abilities (Furnham et al., 2003).

However, the relationship between cognitive abilities and academic performance at the university level may differ somewhat across studies, probably due to differences in measured cognitive abilities (e.g. general, fluid, crystallized), selected instruments for measurement (e.g. choosing tests adapted for highly intelligent students versus tests tailored to the average population), inclusion of different groups of students (e.g. MBA students, psychology students) and different markers of academic performance (e.g. grade point average, seminar performance, absenteeism, scores from essays) (Busato et al., 2000; Farsides and Woodfield, 2002; Furnham and Chamorro-Pre- 
DRUŠ. ISTRAŽ. ZAGREB GOD. 21 (2012), BR. $3(117)$

STR. 715-732

SMRTNIK VITULIĆ, H. PROSEN, $S$. PERSONALITY AND.. muzic, 2004; Lounsbury et al., 2003; Pogačnik, 1994, 2005; Pullmann and Allik, 2008). These differences make it hard to compare and generalize the results from studies that include university students. It must be kept in mind that at all levels of education student grades are also subjectively biased (professors may use different criteria when assessing students' knowledge) and this cannot be entirely avoided (Peček et al., 2008).

Recent studies of the relations between personality traits and academic achievement generally operate under the framework of the Five-Factor Model (FFM) of personality structure (O'Connor and Paunonen, 2007). Results from different studies using FFM indicate that the predictive power of personality traits does decline from primary to higher levels of formal education (Laidra et al., 2007; Smrtnik Vitulić and Zupančič, 2011), but remains important also for university students (Furnham et al., 2003). Some of the FFM traits have been found to be more predictive of adolescents' academic achievement than the others. Conscientiousness has most consistently been identified as relevant to academic success at the university; more conscientious students tend to perform better than less conscientious ones (e.g. Bidjerano and Dai, 2007; Chamorro-Premuzic and Furnham, 2003; O'Connor and Paunonen, 2007; Noftle and Robins, 2007; Rothstein et al., 1994; Steinmayr et al., 2011; Trautwein et al., 2009). The connection between conscientiousness and academic performance has often been interpreted in terms that achievement-oriented, orderly, well organized and hard-working students manage academic assignments more effectively than their less conscientious peers. Research examining the factor openness as a predictor of academic performance has produced mixed results (O'Connor and Paunonen, 2007). In some studies (e.g. Barbaranelli et al., 2003; Farsides and Woodfield, 2002; Gilles and Bailleux, 2001; Lounsbury et al., 2003) openness has been found to be positively correlated with academic performance, but in many other studies authors have failed to find a significant association between those two variables (e.g. Busato et al., 2000; Chamorro-Premuzic and Furnham, 2003). The creative and imaginative nature of open individuals may be disadvantageous in some academic settings, particularly when individuals are required to give convergent answers rather than creative ones (Chamorro-Premuzic and Furnham, 2003). Extraversion has been found to change from positive correlation with academic success in primary school to negative correlation in secondary school and at university (Bratko et al., 2006; Furnham et al., 2003; Laidra et al., 2007; Puklek Levpušček and Zupančič, 2009). The negative correlation between extraversion and academic performance in adolescents has been interpreted in terms of introverted students spending more time studying, as op- 
DRUŠ. ISTRAŽ. ZAGREB GOD. 21 (2012) BR. $3(117)$

STR. $715-732$

SMRTNIK VITULIĆ, H., PROSEN, S.:

PERSONALITY AND.. posed to extraverted ones spending more time socializing (Chamoro-Premuzic and Furnham, 2003). Introverted individuals also have an advantage in written assessments, whereas extraverted may have an advantage at oral examinations (Chamorro-Premuzic and Furnham, 2003). Neuroticism (emotional instability) usually shows no significant associations (e.g. Puklek Levpušček and Zupančič, 2009) or low negative correlations (e.g. Laidra et al., 2007) with school grades since a high level of anxiety under test condition may have a negative effect on academic performance (Chamorro-Premuzic and Furnham, 2003). According to some studies (Laidra et al., 2007; O'Connor and Paunonen, 2007; Zupančič and Kavčič, 2007) agreeableness predicts school success with primary school pupils but is rarely related to academic achievement in adolescents'. This difference may be due to a change from a sociable, less competitive atmosphere at primary school to a more formal atmosphere in secondary school and at university (Chamorro-Premuzic and Furnham, 2003). Primary school atmosphere emphasizes maintaining good relations between teachers and pupils, which leads to better academic adjustment over the course of development (Hair and Graziano, 2003, in Laidra et al., 2007).

Authors of studies with university students (e.g. Chamorro-Premuzic and Furnham, 2003; Chamorro-Premuzic et al., 2005; Nguyen et al., 2005; O'Connor and Paunonen, 2007; Poropat, 2009) included specific groups of students (e.g. psychology students, MBA students) and specific indicators of their academic success (e.g. grade point average, seminar performance, absenteeism, scores from essays). Different competences are encouraged in different university programs and also among subjects within the same study program (Prosen and Smrtnik Vitulić, 2010). As a result, we can expect different associations between personality traits, cognitive abilities, and academic success among different study programs and also among subjects of the same study program. These arguments support the inclusion of more diverse indicators of scholastic achievement, such as grades in specific subjects, rather than just a single overall factor such as GPA (O'Connor and Paunonen, 2007).

Our study extends previous research in several ways. (1) More diverse indicators of students' academic achievement were included (specific students' grades as well as grade point average - GPA) instead of a single one. (2) In predicting academic achievement, we combined the big five personality traits and specific (fluid and crystallized) cognitive abilities instead of including only personality or only general cognitive ability, as done in some previous studies. We expect fluid and crystallized cognitive abilities to explain a different percent- 


\section{METHOD}

\section{Participants}

\section{Measures}

\footnotetext{
1 Only positive grades were analysed since the data including the negative grades were not accessible.
}

age of variance in specific grades. (3) Prediction of academic achievement from personality traits and specific cognitive abilities was performed for different groups of university students instead of a single group in order to check for possible differences across different study programs.

Two groups of students participated in the study. The first group was composed of 203 primary education students, educated to work in the first five grades of elementary school ( $97 \%$ girls), aged 18.6 to 25.1 years ( $\mathrm{M}=19.8$ years, $\mathrm{SD}=8$ months). The second group included 80 students of social pedagogy $(96 \%$ girls), aged 18.1 to 23.2 years $(\mathrm{M}=19.5, \mathrm{SD}=6$ months). There were two generations (enrolled in 2008 and 2009) in each group of undergraduate students at the Faculty of Education, Ljubljana. Both generations were tested in the first year of their study. All the participants were fully informed about the purpose and methods of the study and their participation was voluntary. Each student gave written permission for recording their grades from the internal faculty register.

\section{Academic achievement}

Final grades for all subjects that the students had already passed were collected from the faculty register at the end of their first academic year. ${ }^{1}$ For primary education students, GPA is the mean of the final grades from eight subjects: Developmental Psychology with Pedagogical Practice, Didactics with Pedagogical Practice, Foreign Language - English or German, Introduction to Literature, Mathematics, Natural Sciences, Music and Slovene Language I. For students of social pedagogy GPA is the mean of the final grades from the following eight subjects: Developmental Psychology I, Foreign Language, Fundamentals of Social Pedagogy I and II, Pedagogical Methodology I and II, Pedagogical Psychology, Social Integration I and II, Theoretical Conceptions of Difficulties and Theory of Education.

Due to the large number, subjects were arranged into smaller groups, according to similarity of academic disciplines. Music and Foreign Language were excluded because of their specific contents. For the group of primary education students, average grades for three groups of similar subjects were calculated: (1) psychology and didactics (including grades from Developmental Psychology with Pedagogical Practice and Didactics with Pedagogical Practice), (2) Slovene lan- 
DRUŠ. ISTRAŽ. ZAGREB GOD. 21 (2012), BR. $3(117)$

STR. $715-732$

SMRTNIK VITULIĆ, H., PROSEN, S.:

PERSONALITY AND.. guage (including grades of Slovene Language I and Introduction to Literature) and (3) natural sciences and mathematics (including grades from Natural Sciences and Mathematics). For the group of social pedagogy students, the average grades were also calculated for the three groups of subjects: (1) psychology and education (including grades from Developmental Psychology I, Pedagogical Psychology and Theory of Education), (2) social pedagogy subjects (including grades from Fundamentals of Social Pedagogy I and II and Theoretical Conceptions of Difficulties in Social Integration I and II) and (3) methodology (including grades from Methodology I and II).

Students in Slovenia are graded on a scale of 1 to 10 ( 1 to $5=$ not sufficient, $6=$ sufficient, $7=\operatorname{good}, 8$ and $9=$ very good, $10=$ excellent). The majority of grades are gained through written exams. The mean GPA for primary education students was $7.80(\mathrm{SD}=0.70)$ and for students of social pedagogy, 8.29 $(\mathrm{SD}=0.56)$. Students of social pedagogy had a significantly higher GPA than primary education students $(\mathrm{t}=-7.57, \mathrm{df}=281$, $\mathrm{p}<0.00)$.

\section{Specific cognitive abilities}

Two measures of cognitive abilities were employed in this study.

(a) Verbal ability test - "Foreign words" - measures crystallized intelligence, as defined by Horn/Cattell intelligence theory (Pogačnik, 2005). It includes 54 items, where participants have to match a foreign word with one out of four Slovene expressions with the same meaning. The test is administered in 5 minutes. Internal reliability of the test is high $(\alpha=0.94)$.

The test was standardized in Slovenia and its manual provides norms for different age groups (Pogačnik, 2005). The average test score is 100 with a standard deviation of 15 . The mean result for primary education students was $113.44(\mathrm{SD}=6.13)$ and for students of social pedagogy $114.42(S D=6.50)$. The mean results of the two groups were not significantly different $(\mathrm{t}=-1.11, \mathrm{df}=281, \mathrm{p}>0.05)$.

(b) Non-verbal ability test - "Test of series" - is a reliable measure of fluid intelligence, as defined by Horn/Cattell intelligence theory (Pogačnik, 1994). 45 items include analysis of a series of geometric figures and demand their logical continuation. The test is administered in 20 minutes. Items show a strong internal reliability $(\alpha=0.86)$. The test was standardized in Slovenia (Pogačnik, 1994).

The manual provides norms for different age groups. The average test score is 100 with a standard deviation of 15 . For primary education students the mean result of the test was $111.09(\mathrm{SD}=12.34)$ and for students of social pedagogy 108.06 
DRUŠ. ISTRAŽ. ZAGREB GOD. 21 (2012), BR. 3 (117),

STR. 715-732

SMRTNIK VITULIĆ, H. PROSEN, $S$.

PERSONALITY AND.
$(\mathrm{SD}=13.31)$. The mean results of the two groups of students were not significantly different $(t=1.70, d f=281, p>0.05)$.

\section{Personality traits}

Participants completed the adapted and normalized Slovene version (Caprara et al., 1997) of the "Big Five Questionnaire" (BFQ). This is a 132 item measure of 10 mid-level personality traits. Students provided self-reports on a 5-point Likert scale (from $1=$ not true for me to $5=$ entirely true for me). The 10 BFQ mid-level scales form five robust personality factors: energy (dynamism and dominance), agreeableness (cooperativeness/empathy and warmth/friendliness), conscientiousness (scrupulousness and perseverance), emotional stability (emotion control and impulse control), and openness (cultural openness and openness to experience). Across Slovene normative groups, these factors explain $83 \%$ of the total variance and they are strongly internally coherent, moderately stable across contexts and age groups (Caprara et al., 1997). The internal reliabilities (Cronbach $\alpha_{s}$ ) for the scales of energy, agreeableness, conscientiousness, emotional stability and openness for the primary education students were $0.60,0.54,0.72$, 0.75 and 0.71 , respectively and for the students of social pedagogy were $0.65,0.64,0.63,0.79$ and 0.58 , respectively.

The BFQ manual reports an average score of 100 with a standard deviation of 15 for each personality trait (Caprara et al., 1997). The results from both student groups were within average for energy, agreeableness, conscientiousness and emotional stability, but below average for openness (see results in Prosen and Smrtnik Vitulić, 2010). The results of five personality traits were not significantly different between primary education students and students of social pedagogy (for energy $t=1.95$, for agreeableness $t=0.23$, for conscientiousness $t=0.72$, for emotional stability $t=0.80$ and for openness $\mathrm{t}=0.16$, all $\mathrm{df}_{\mathrm{s}}=281$, all $\mathrm{p}_{\mathrm{s}}>0.05$ ).

\section{Procedure and statistical analysis}

Personality and cognitive abilities' measures were administrated at the beginning of the first academic year, during the lectures. Each student completed a BFQ inventory (Caprara et al., 1997), as well as the two different cognitive ability tests, namely "Foreign words" (Pogačnik, 2005) and "Test of series" (Pogačnik, 1994). One or the other of the authors was present during completion of the test to ensure proper administration. Student grades were collected from the faculty internal register at the end of the study year.

Pearson correlations between student grades, five personality traits and the two cognitive abilities tests were calculat- 
DRUŠ. ISTRAŽ. ZAGREB GOD. 21 (2012),

BR. $3(117)$

STR. 715-732

SMRTNIK VITULIĆ, H., PROSEN, S.:

PERSONALITY AND. ed. Then, for each group of students, hierarchical multiple regression analyses were conducted to test predictive relations of the two cognitive ability tests (first step) and personality traits (second step) with student grades. Hierarchical regressions were performed to test the incremental validity (over cognitive abilities) of the students' personality.

\section{RESULTS}

\section{Correlations among student grades, their cognitive abilities and personality traits}

Table 1 shows correlations of student GPA and specific grades with the two cognitive abilities tests and the personality traits (energy, agreeableness, conscientiousness, emotional stability, and openness).

\begin{tabular}{|c|c|c|c|c|c|c|c|c|}
\hline & \multicolumn{4}{|c|}{ Primary education student grades } & \multicolumn{4}{|c|}{ Social pedagogy student grades } \\
\hline & $\mathrm{GPA}_{1}$ & Psy-Did & Slo & Sci-Ma & $\mathrm{GPA}_{2} \mathrm{P}$ & Psy-Edu & Soc. Ped. & Mtd \\
\hline \multicolumn{9}{|l|}{ Cognitive abilities: } \\
\hline "Foreign words" & -0.08 & -0.03 & -0.02 & -0.09 & $0.31^{*}$ & 0.30 & 0.17 & 0.03 \\
\hline "Test of series" & 0.00 & -0.10 & -0.04 & $0.18^{* *}$ & 0.10 & 0.12 & -0.03 & 0.20 \\
\hline \multicolumn{9}{|l|}{ Personality traits: } \\
\hline Energy & 0.02 & -0.03 & 0.00 & 0.07 & $0.36^{* *}$ & $0.33^{* *}$ & 0.09 & 0.33 \\
\hline Agreeableness & 0.01 & -0.04 & -0.04 & -0.03 & 0.08 & 0.14 & -0.05 & -0.07 \\
\hline Conscientiousness & $0.17^{* *}$ & $0.33^{* *}$ & $0.19^{* *}$ & 0.05 & $0.39^{* *}$ & $0.27^{*}$ & $0.34^{* *}$ & 0.19 \\
\hline Emotional stability & 0.08 & -0.08 & 0.01 & 0.11 & 0.12 & 0.10 & 0.05 & 0.14 \\
\hline Openness & 0.04 & 0.03 & 0.02 & 0.08 & $0.30^{* *}$ & 0.15 & -0.06 & 0.18 \\
\hline
\end{tabular}

Notes: $\mathrm{GPA}_{1}=$ grade point average in the first year of Primary teacher education program, Psy-Did $=$ psychology and didactics, Slo $=$ Slovene language, Sci-Ma $=$ natural sciences and mathematics, $\mathrm{GPA}_{2}=$ grade point average in the first year of Social pedagogy education program, Psy-Edu = psychology and education, Soc. Ped. = social pedagogy subjects, $\mathrm{Mtd}=$ methodology. ${ }^{*} \mathrm{p}<0.05$ and ${ }^{* *} \mathrm{p}<0.01$

(1) TABLE 1

Correlations of personality traits and two specific cognitive abilities of students' and their grades
The correlation between grades and the cognitive abilities tests was low. "Foreign words" ability test significantly and positively correlated with GPA, but only for students of social pedagogy. "Test of series" was significantly and positively linked to the "natural sciences and mathematics" grade for primary education students.

The correlation between grades and the big five personality traits was low to modest. Conscientiousness had a significant correlation with GPA's in both groups of students. This personality trait also significantly and positively correlated with the grades in "psychology and didactics" and "Slovene language", for primary education students, and with the grades in "psychology and education" and "social pedagogy sub- 
jects", for students of social pedagogy. Energy significantly and positively correlated with the GPA and grades in "psychology and education", for social pedagogy students. The final trait, openness, was significantly and positively linked to GPA only in the social pedagogy student group.

\section{Predicting student grades from cognitive abilities and personality traits}

For primary education students, both cognitive abilities tests and all five personality traits together explained the variance of 2\% in GPA, $8 \%$ in "psychology and didactics", $1 \%$ in "Slovene language", and 3\% in "natural sciences and mathematics" (see Table 2). The prediction was significant only for the "psychology and didactics" grade $(\mathrm{p}<0.01)$. For social pedagogy

U. TABLE 2

Hierarchical regressions: cognitive abilities and personality traits as predictors of grades in primary education students students, both cognitive abilities tests and all five personality traits accounted for $44 \%, 24 \%, 17 \%$ and $30 \%$ of the variance in student GPA, and grades in "psychology and education", "social pedagogy subjects" and "methodology" grades, respectively (see Table 3). All those predictions were significant $(\mathrm{p}<0.01)$.

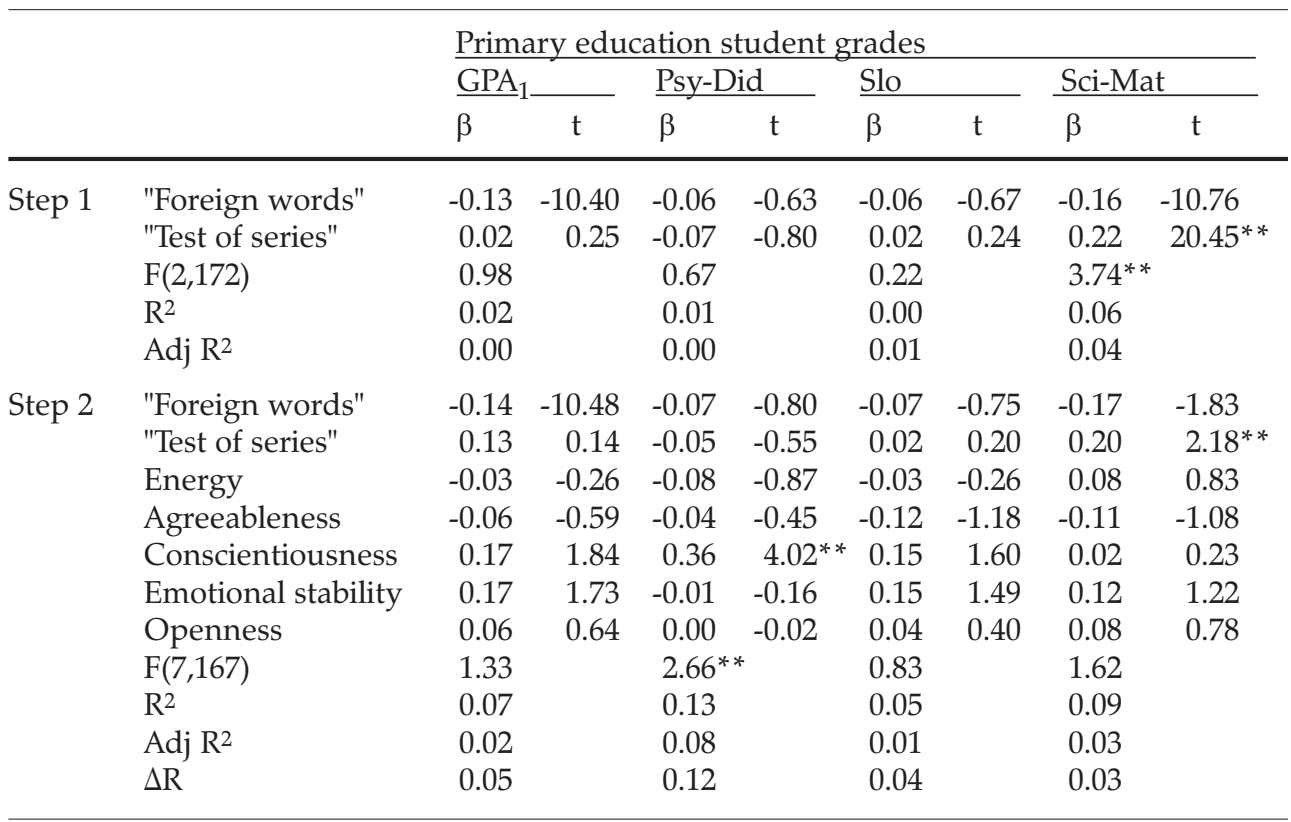

Notes: $\mathrm{GPA}_{1}=$ grade point average in the first year of Primary teacher education program, Psy-Did $=$ psychology and didactics, Slo $=$ Slovene language, Sci-Mat $=$ natural sciences and mathematics; $\Delta R=R$ square change. ${ }^{*} \mathrm{p}<0.05$ and ${ }^{* *} \mathrm{p}<0.01$

The personality of primary education students provided unique predictive information on the "psychology and didactics" grade over and above the results from the cognitive abili- 
(1) TABLE 3 Hierarchical regressions: cognitive abilities and personality traits as predictors of grades in social pedagogy students gy students, the second step in hierarchical regression model with cognitive abilities and personality traits represented a substantial improvement in the predictive power of the GPA and for grades in, "psychology and education", "social pedagogy subjects" and "methodology", relative to the predictions based only on the cognitive abilities tests (see $\Delta \mathrm{R}$ in Table 3 for comparison).



Notes: $\mathrm{GPA}_{1}=$ grade point average in the first year of Social pedagogy education program, Psy-Edu = psychology and education, Soc. Ped. = social pedagogy subjects, Mtd = methodology; $\Delta \mathrm{R}=\mathrm{R}$ square change. ${ }^{*} \mathrm{p}<0.05$ and ${ }^{* *} \mathrm{p}<0.01$.

Among the two cognitive abilities tests, which were introduced in the first step of the regression analyses, only the result of the "Test of series" was a significant predictor of the "science and mathematics" grade for primary education students. For social pedagogy students the result of "Foreign words" was a significant predictor of GPA.

Among the five personality traits, which were introduced in the second step of regression analyses, conscientiousness was the only significant predictor of "psychology and didactics" grade for primary education students. For social pedagogy students conscientiousness was a significant predictor of their GPA and for grades in "psychology and education" and "social pedagogy subjects". For social pedagogy students, high energy was a significant predictor of GPA and grades in "psychology and education" and "methodology". Low agreeableness was a significant predictor of GPA and the grade in 
DRUŠ. ISTRAŽ. ZAGREB GOD. 21 (2012), BR. $3(117)$

STR. 715-732

SMRTNIK VITULIĆ, $\mathrm{H}$. PROSEN, $S$.

PERSONALITY AND.. "methodology". We can conclude that among personality traits conscientiousness was the only significant predictor for some grades for both student groups.

For primary education and social pedagogy students, prediction models, based upon the results of the two cognitive abilities tests and upon the results of the five personality traits, were not quite stable (see $\mathrm{R}^{2} \mathrm{vs}$. Adj. $\mathrm{R}^{2}$ in tables 2 and 3 ) since they did not explain an equal amount of variance in the GPA.

\section{DISCUSSION}

The present study examined the relationship between student grades, specific cognitive abilities and personality traits in two groups of Slovene university students. Two generations of primary education students and two generations of social pedagogy students were included in the study.

The specific cognitive abilities were associated only with certain student grades in our study. For example, the "Test of series", measuring fluid cognitive abilities had a significant correlation with the "natural sciences and mathematics" grade in primary education students and the "Foreign words" ability test, measuring crystallized cognitive abilities, significantly correlated with the GPA of social pedagogy students. Significant correlations between some cognitive abilities and academic achievement in students were also found in previous studies (e.g. Farsides and Woodfield, 2003; Furnham and Chamorro-Premuzic, 2004).

Some studies confirmed associations between personality traits and the students' academic performance, especially regarding conscientiousness (e.g. Furnham and Chamorro-Premuzic, 2004; Lounsbury et al., 2003; Steinmayr et al., 2011; Trautwein et al., 2009). Our results revealed that for both groups of students, conscientiousness was significantly and positively associated with their GPA. For primary education students, conscientiousness correlated with "psychology and didactics" and "Slovene language" grades as well, whereas for students of social pedagogy conscientiousness also correlated with grades in "psychology and education" and "social pedagogy subjects" grades. In our study, energy was significantly and positively associated with GPA and grades in "psychology and education" for students of social pedagogy. For that group of students, openness also had a significant and positive link to the GPA. To the contrary, the majority of previous empirical studies did not confirm a positive association of extraversion (with energy comparable personality trait, which doesn't include dynamism and dominance) and openness with university academic performance (e.g. O'Connor and Paunonen, 2007).

Results of hierarchical regression analyses showed that those social pedagogy students, who understood foreign words 
DRUŠ. ISTRAŽ. ZAGREB GOD. 21 (2012),

BR. $3(117)$

STR. $715-732$

SMRTNIK VITULIĆ, H., PROSEN, S.:

PERSONALITY AND.. better, achieved higher academic success (GPA) than others. Their knowledge of foreign expressions may have contributed to their general academic performance due to the numerous scientific books and articles they had to understand during their study. Among primary education students, good results on the "Test of series" predicted their "natural sciences and mathematics" grade as these subjects demand mathematical and logical reasoning. The predictive power of both cognitive abilities tests was low.

The aforementioned prediction of academic performance, that was mostly insignificant for both groups of students, may be explained in terms of (1) the specific subject demands and (2) the selected sample. First, the results of the two cognitive abilities tests did not significantly differ between primary education and social pedagogy students (see results in "Measures - Specific Cognitive Abilities" of this article). Thus, we can conclude that the relation between verbal or non-verbal cognitive abilities and academic performance was mainly conditioned by different competences that were encouraged within certain university programs and by different subjects within the same study program. Second, the mean results of verbal and non-verbal tests for both groups of students were compared with the norms, presented in test manuals (Pogačnik, 1994, 2005). The results for both groups were above average, but not extremely high. Since the selection procedure for study programs is based on previous academic excellence (high achievement in secondary school), the level of cognitive abilities in participants was expected to be above average. Future research may require, as recommended by other authors, the use of more discriminatory tests for measuring intelligence in elite university students (e.g. Furnham et al., 2003).

The results of hierarchical regression models showed that for social pedagogy students, personality self-ratings (included in the second step, after cognitive abilities) provided unique predictive information on the GPA and on grades in "psychology and education", "social pedagogy subjects" and "methodology", and represented a more powerful predictor of their performance than cognitive abilities. These results are in accordance with recent findings of the unique predictive value of the students' personality of academic achievement, after specific cognitive abilities had been accounted for (e.g. Laidra et al., 2007). For primary education students, personality provided important predictive information on the grade for "psychology and didactics", over and above the cognitive abilities results - meaning that personality traits were not as important for academic success in primary education students as they were for social pedagogy students. 
DRUŠ. ISTRAŽ. ZAGREB GOD. 21 (2012), BR. $3(117)$

STR. 715-732

SMRTNIK VITULIĆ, H., PROSEN, $S$. PERSONALITY AND.
Among the big five personality traits conscientiousness was a significant predictor of the "psychology and didactics" grade for primary education students and of GPA and grades in "psychology and education" and "social pedagogy subjects" for students of social pedagogy. The reason that conscientiousness was a better predictor of grades for social pedagogy students rather than for primary education students may lie in the difference in the level of effort that students from those programs are prepared to invest in their study. In conversation with each group of students we learned that social pedagogy students were prepared to invest more effort towards achieving better grades than their colleagues who would become primary education teachers (Smrtnik Vitulić and Prosen, 2011). In accordance with the aforementioned, the GPA of primary education students was lower than the GPA of social pedagogy students at the end of the first year of their study (results are shown in "Measures - Academic Achievement" of this article). We speculate that conscientious students attained higher levels of academic achievement, if they were motivated to obtain good grades. If so, being persistent, dutiful, meticulous, and persevering may have played a beneficial role in the effort they put into studying (Smrtnik Vitulić and $\mathrm{Zu}-$ pančič, 2011).

Motivation in students may also be mediated through the professors' expectations regarding academic achievement. In conversations with many professors at the Faculty of Education, the authors of this article recognised that the majority of them had higher expectations of academic achievement for social pedagogy students than for primary education students. These expectations, as observed by other authors (e.g. Khattab, 2005), could affect the expectations that students have regarding their academic success and if positive, will contribute to their motivation.

Among personality traits, high energy was a significant predictor of the GPA and grades in "psychology and education" and "methodology" of social pedagogy students. Different authors have identified that extraversion (with energy comparable personality trait, which doesn't include dynamism and dominance) predicted higher grades in school-age children but lower grades in adolescents (Bratko et al., 2006; Furnham et al., 2003; Laidra et al., 2007; Puklek Levpušček and Zupančič, 2009). Where the correlation among extraversion and student grades was significant, the authors explained this significance as the result of two factors: oral examinations and project work that require verbal interactions (Furnham and Chamorro-Premuzic, 2004). Under such circumstances the extraverted students, who were more communicative and open, 
DRUŠ. ISTRAŽ. ZAGREB GOD. 21 (2012) BR. $3(117)$

STR. $715-732$

SMRTNIK VITULIĆ, H., PROSEN, S.:

PERSONALITY AND.. did better at presenting their knowledge. However, this explanation cannot be applied in the interpretation of our results. Student grades in our research were not based on the above mentioned types of examination but mostly on written exams and the energy (in BFQ) does not match the extraversion personality trait. The question of why high energy contributed to better grades in our research thus opens new explanatory possibilities. Maybe some unknown moderator variables (e.g. dynamism helps the student to obtain more relevant study materials and consequently reach better result at written exam) were responsible for high level of energy exerting a positive influence on specific academic grades of the social pedagogy students.

The results of regression analyses also showed that for students of social pedagogy low agreeableness was a significant predictor of the GPA and "methodology" grades. In other studies, agreeableness was rarely related to academic achievement in students (O'Connor and Paunonen, 2007). One reason may be that students of social pedagogy, who were less cooperative, more suspicious and strict (low level of agreeableness) perhaps didn't agree with the subject content and sought alternate ways of understanding. As a result, they could understand some of the subject content better than students with 'high agreeableness' and consequently achieved higher grades in general (GPA) and in specific subjects (e.g. "methodology").

Cognitive abilities and personality traits together were significant predictors in primary education students of grades only in "psychology and didactics", whereas in social pedagogy students they were predictive for all their grades. Since both groups of students in our research were equal regarding their cognitive abilities and all five personality traits, it can be assumed that the differences stemmed from the different study programs, and from differences in motivation to receive good grades. It must be also taken into consideration that school grades are always subjectively biased (Peček et al., 2008). Different professors may have different criteria when assessing a student's knowledge: e.g. exam questions may demand different levels of understanding and knowledge; exam questions may require different kinds of thinking - convergent or divergent; some professors may prefer short answers, whereas others prefer long answers, etc.

\section{CONCLUSION}

In conclusion, the results of the present study showed that specific cognitive abilities and the five personality traits had different associations with student grades within the same program and across different university programs. The strength 
DRUŠ. ISTRAŽ. ZAGREB GOD. 21 (2012), BR. $3(117)$

STR. 715-732

SMRTNIK VITULIĆ, H. PROSEN, $S$. PERSONALITY AND. of our study lies in the fact that: specific components of academic performance were examined, instead of taking into account only a single overall indicator of academic success such as GPA; the prediction of academic success included personality and different cognitive abilities measures; and two different groups of students were compared.

However, the sample of students was relatively small, including predominantly females and the predictive relations were investigated within a specific educational system. For the future, other specific non-cognitive variables (e.g. motivation, interests and study habits) and different cognitive ability tests should also be included in predicting academic achievement. The differences in grading criteria among professors could also be examined. It would be interesting to use mid-level personality traits as predictors of student performance and find out whether they add any incremental validity over the robust traits (e.g. Chamorro-Premuzic and Furnham, 2003; O'Connor and Paunonen, 2007; Smrtnik Vitulić and Zupančič, 2011).

We believe that increasing knowledge of the factors that predict academic achievement has important implications for education. It allows educators to foresee who will perform better or worse in specific university programs, and to understand better alternate ways to optimize study programs. Exploring these different factors should be encouraged in the future.

\section{REFERENCES}

Barbaranelli, C., Caprara, G. V., Rabasca, A., \& Pastorelli, C. (2003), A Questionnaire for Measuring the Big Five in Late Childhood. Personality and Individual Differences, 34 (4): 645-664. doi:10.1016/S01918869(02)00051-X

Bidjerano, T., \& Dai, D. Y. (2007), The Relationship between the Big-Five Model of Personality and Self-Regulated Learning Strategies. Learning and Individual Differences, 17 (1): 69-81. doi:10.1016/j.lindif.2007. 02.001

Bratko, D., Chamorro-Premuzic T., \& Saks, Z. (2006), Personality and School Performance: Incremental Validity of Self- and Peer-Rating over Intelligence. Personality and Individual Differences, 41 (1): 131-142. doi:10.1016/j.paid.2005.12.015

Busato, V. V., Prins, F. J., Elshout, J. J., \& Hamaker, C. (2000), Intellectual Ability, Learning Style, Personality, Achievement Motivation and Academic Success of Psychology Students in Higher Education. Personality and Individual Differences, 29 (6): 1057-1068. doi:10.1016/ S0191-8869(99)00253-6

Caprara, G. V., Barbaranelli, C., Borgogni, L., Bucik V., \& Boben, D. (1997), Model "velikih pet". Priročnik za merjenje strukture osebnosti BFQ-BFO [The Big Five Model. The Structure of Personality BFQ-BFO: Assessment Manual]. Ljubljana, Center za psihodiagnostična sredstva. 
DRUŠ. ISTRAŽ. ZAGREB GOD. 21 (2012), BR. $3(117)$

STR. $715-732$

SMRTNIK VITULIĆ, H., PROSEN, S.: PERSONALITY AND.
Chamorro-Premuzic, T., \& Furnham, A. (2003), Personality Traits and Academic Examination Performance. European Journal of Personality, 17 (3): 237-250. doi:10.1002/per.473

Chamorro-Premuzic, T., Furnham, A., Dissou, G., \& Heaven, P. (2005), Personality and Preference for Academic Assessment. A Study with Australian University Students. Learning and Individual Differences, 15 (4): 247-256. doi:10.1016/j.lindif.2005.02.002

Chamorro-Premuzic, T., \& Furnham, A. (2008), Personality, Intelligence and Approaches to Learning as Predictors of Academic Performance. Personality and Individual Differences, 44 (7):1596-1603. doi:10. 1016/j.paid.2008.01.003

Di Fabio, A., \& Palazzeschi, L. (2009), An In-Depth Look at Scholastic Success: Fluid Intelligence, Personality Traits or Emotional Intelligence? Personality and Individual Differences, 46 (5-6): 581-585. doi:10. 1016/j.paid.2008.12.012

Farsides, T., \& Woodfield, R. (2002), Individual Differences and Undergraduate Academic Success: The Roles of Personality, Intelligence and Application. Personality and Individual Differences, 34 (7): 1225-1243.

Furnham, A., \& Chamorro-Premuzic, T. (2004), Personality and Intelligence as Predictors of Statistics Examination Grades. Personality and Individual Differences, 37 (5): 943-955. doi:10.1016/j.paid.2003.10.016 Furnham, A., Chamorro-Premuzic, T., \& McDougall, F. (2003), Personality, Cognitive Ability, and Beliefs About Intelligence as Predictors of Academic Performance. Learning and Individual Differences, 14 (1): 47-64

Gilles, P.-Y., \& Bailleux, C. (2001), Personality Traits and Abilities as Predictors of Academic Achievement. European Journal of Psychology of Education, XVI (1): 3-15. doi:10.1007/BF03172991

Horn, J. L., \& Cattell, R. B. (1966), Refinement and Test of the Theory of Fluid and Crystallized Intelligence. Journal of Educational Psychology, 57 (5): 253-270. doi:10.1037/h0023816

Khattab, N. (2005), The Effects of High School Context and Interpersonal Factors on Students' Educational Expectations: A Multi-Level Model. Social Psychology of Education, 8 (1): 19-40. doi:10.1007/s11218004-8976-6

Laidra, K., Pullmann, H., \& Allik, J. (2007), Personality and Intelligence as Predictors of Academic Achievement: A Cross-Sectional Study from Elementary to Secondary School. Personality and Individual Differences, 42 (3): 441-451. doi:10.1016/j.paid.2006.08.001

Leeson, P., Ciarrochi, J., \& Heaven, P. C. L. (2008), Cognitive Ability, Personality, and Academic Performance in Adolescence. Personality and Individual Differences, 45 (7): 630-635. doi:10.1016/j.paid.200807.006

Lounsbury, J. W., Sundstrom, E., Loveland, J. M., \& Gibson, L. W. (2003), Intelligence, "Big Five" Personality Traits, and Work Drive as Predictors of Course Grade. Personality and Individual Differences, 35 (6): 1231-1239. doi:10.1016/S0191-8869(02)00330-6

Nguyen, N. T., Larry, C. A., \& Fraccastoro, K. (2005), Personality Predicts Academic Performance: Exploring the Moderating Role of Gender. Journal of Higher Education Policy and Management, 27 (1): 105-117. doi:10.1080/13600800500046313 
DRUŠ. ISTRAŽ. ZAGREB GOD. 21 (2012), BR. 3 (117)

STR. 715-732

SMRTNIK VITULIĆ, H. PROSEN, $S$. PERSONALITY AND.
Noftle, E. E., \& Robins, R. W. (2007), Personality Predictors of Academic Outcomes: Big Five Correlates of GPA and SAT Scores. Journal of Personality and Social Psychology, 93 (1): 116-130. doi:10.1037/0022-3514. 93.1.116

O'Connor, M., \& Paunonen, S. V. (2007), Big Five Personality Predictors of Post-Secondary Academic Performance. Personality and Individual Differences, 43 (5): 971-990. doi:10.1016/j.paid.2007.03.017

Peček, M., Zuljan, M. V., Čuk, I., \& Lesar, I. (2008), Should Assessment Reflect Only Pupils' Knowledge? Educational Studies, 34 (2): 73-82.

Pogačnik, V. (1994), TN: test nizov. Priročnik. [TN: Test of Series: Assessment Manual]. Ljubljana, Produktivnost, Center za psihodiagnostična sredstva.

Pogačnik, V. (2005). Test verbalne sposobnosti "Tujke" - TVS, 2. izdaja [Verbal Ability Test - "Foreign Words": Assessment Manual (2nd ed.)].

Poropat, A. E. (2009), A Meta-Analysis of the Five-Factor Model of Personality and Academic Performance. Psychological Bulletin, 135 (2): 322-338. doi:10.1037/a0014996

Prosen, S., \& Smrtnik Vitulić, H. (2010), Značilnosti študentov razrednega pouka in socialne pedagogike [Characteristics of Students of Primary Teacher Education and Social Pedagogy]. Socialna pedagogika, 14 (3): $327-346$

Puklek Levpušček, M., \& Zupančič, M. (2009), Osebnostni, motivacijski in socialni dejavniki učne uspešnosti [Personal, Motivational and Social Factors of School Achievement]. Ljubljana, Znanstvenoraziskovalni inštitut Filozofske fakultete.

Pullmann, H., \& Allik, J. (2008), Relations of Academic and General Self-Esteem to School Achievement. Personality and Individual Differences, 45 (6): 559-564. doi:10.1016/j.paid.2008.06.017

Rothstein, M. G., Paunonen, S. V., Rush, J. C., \& King, G. A. (1994), Personality and Cognitive Ability Predictors of Performance in Graduate Business School. Journal of Educational Psychology, 86 (4): 516-530. doi:10.1037//0022-0663.86.4.516

Smrtnik Vitulić, H., \& Prosen, S. (2011), Osebnost in samospoštovanje kot dejavnika učne uspešnosti študentov [Personality and Self-Esteem as Predictors of Students' Academic Achievement]. Socialna pedagogika, 15 (1): 1-20.

Smrtnik Vitulić, H., \& Zupančič, M. (2010), Robust and Mid-Level Personality Traits as Predictors of Adolescents' Academic Achievement in Secondary School. Suvremena psihologija, 13 (2): 203-219.

Smrtnik Vitulić, H., \& Zupančič, M. (2011), Personality Traits as a Predictor of Academic Achievement in Adolescents. Educational Studies, 37 (2): 127-140.

Steinmayr, R., Bipp, T., \& Spinath, B. (2011), Goal Orientations Predict Academic Performance Beyond Intelligence and Personality. Learning and Individual Differences, 21 (2): 196-200. doi:10.1016/j.lindif.2010. 11.026

Sternberg, R. J. (1985), Beyond IQ: A Triarchic Theory of Human Intelligence. Cambridge, New York, Cambridge University Press. 
DRUŠ. ISTRAŽ. ZAGREB GOD. 21 (2012)

BR. $3(117)$

STR. $715-732$

SMRTNIK VITULIĆ, H., PROSEN, S.:

PERSONALITY AND.
Trautwein, U., Lüdtke, O., Roberts, B. W., Schnyder, I., \& Niggli, A. (2009), Different Forces, Same Consequences: Conscientiousness and Competence Beliefs are Independent Predictors of Academic Effort and Achievement. Journal of Personality and Social Psychology, 97 (6): 1115-1128. doi:10.1037/a0017048

Zupančič, M., \& Kavčič, T. (2007), Otroci od vrtca do šole: razvoj osebnosti in socialnega vedenja ter učna uspešnost prvošolcev [The Children from Pre-School to School: Development of Personality and Social Behaviour, and Academic Achievement in First Grades]. Ljubljana, Znanstvenoraziskovalni inštitut Filozofske fakultete.

\section{Ličnost i kognitivne sposobnosti kao prediktori akademskog uspieha studenata sveučilišta}

Helena SMRTNIK VITULIĆ, Simona PROSEN

Pedagoški fakultet, Ljubljana

Pet velikih dimenzija ličnosti i specifične kognitivne sposobnosti studenata upotrijebljene su u ovoj studiji za predviđanje njihova akademskog uspjeha: prosjek ocjena i ocjena iz pojedinih kolegija. Dvije generacije studenata prve godine fakulteta sudjelovale su u istraživanju: 203 studenta razredne nastave i 80 studenata socijalne pedagogije. Hijerarhijskom regresijskom analizom, neverbalne su kognitivne sposobnosti, uključene u prvom koraku analize, objasnile $4 \%$ varijance ocjena iz "znanosti i matematike" studenata razredne nastave, dok su verbalne kognitivne sposobnosti objasnile $7 \%$ varijance prosjeka ocjena studenata socijalne pedagogije. Pet velikih dimenzija ličnosti, koje su uključene u drugom koraku analize, značajno su poboljšale predviđanje ocjena iz "psihologije i didaktike" studenata razredne nastave i ukupnih ocjena studenata socijalne pedagogije, $u$ odnosu na predviđanja koja se temelje samo na testovima kognitivnih sposobnosti. Među pet velikih dimenzija ličnosti, mjerenih uz pomoć BFQ (Caprara i sur., 1997.), savjesnost je bila jedini značajan prediktor pojedinih ocjena za studente obiju skupina.

Ključne riječi: akademski uspjeh, studenti, kognitivna sposobnost, ličnost, pet velikih dimenzija 